\title{
PERSONNEL MANAGEMENT OF CONSTRUCTION ENTERPRISES
}

\section{УПРАВЛІННЯ ПЕРСОНАЛОМ ДОРОЖНЬО-БУДІВЕЛЬНИХ ПІДПРИЕМСТВ}

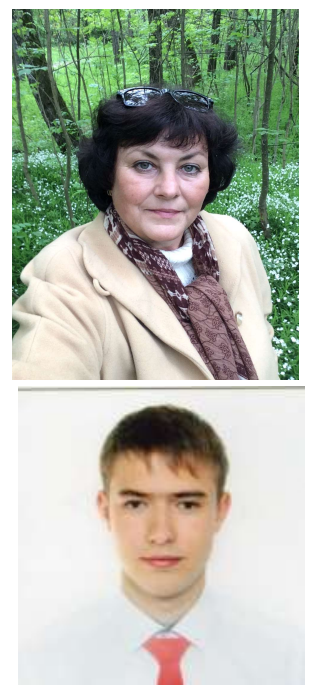

Grechan A.P., Doctor of Economics, Professor, National Transport University, Professor of Economics, e-mail: grechan.ap@gmail.com, tel. +380674494014, Ukraine, 01010, Kyiv, street M. Omelyanovich-Pavlenko, 1.

$$
\text { https://orcid.org/0000-0002-4067-4371 }
$$

Yatsenko B.I., Candidate of Economic Sciences (Ph.D.), State University of Infrastructure and Technologies, Senior Lecturer of the Department of Transport Technologies, tel. 0939989850, Ukraine, 04071, Kyiv, vul. Kyrylivska, 9.

https://orcid.org/0000-0001-7080-7254

Petrovich V.V, Candidate of Technical Sciences, Professor, Senior Researcher, Professor of the Transportation Construction and Property Management Department, National Transport University. e-mail: petrovichvv60@ukr.net, tel. +3804428027338, Ukraine, 01010, Kyiv, street M. Omelyanovicha-Pavlenka, 1, room 138.,

https://orcid.org/0000-0003-0422-2535

Usychenko O., PhD, Candidate of Technical Sciences, Associate Professor, Professor, Department of Transportation Construction and Property Management, National Transport University https://orcid.org/0000-0002-7482-8420

Abstract. In the thesis features of personnel management in the construction industry. The conceptual framework of the system of personnel management of the building, which is based on enhancing the role of staff, compared with traditional methods of management in the domestic construction companies. Easy to assess the quality of staff building company from a position of the enterprise, based on the factorial-target approach, which is to allocate the defining problems of structural units that must be solved to achieve this goal, identification and evaluation of relevant key features of staff.

The quantitative relationship between the components of quality of construction personnel and construction of net income/ 
Assessment of quality of staff positions offered to investors by the criterion of «cost of personnel», which is defined as net sales of construction works, reduced by the amount of material costs and depreciation of fixed assets of the organisation.

The mechanism of stimulation of the construction workers, depending on the achieved level of quality of works. The complex of measures aimed at improving the «qualifying component» as staff of the construction industry.

Keywords: Personal Management, the construction, the quality of personnel, incentives, raising and qualifications.

Formulation of the problem. Staffing is a key point in evaluating of constraction organization as a whole in terms of its ability to perform a certain type of work, the feasibility of investing, choosing a reliable partner and more. Indeed, the quality of performed work, the effectiveness of management decisions, and therefore the final results are depends on the qualification and experience of the organization personnel, the social and psychological climate in the team, the ingenuity of individual employees, etc.

Analysis of recent publications. The work of such outstanding scientists as S. Adams, M. Armstrong, V. Vrum, A. Maslow, M. Porter, T. Stevens, F. Whiteley, F. Herzberg, T. Yu. Bazarova, B.LEremina, A.Ya. Kibanova, S.I. Samigina, L.D. Stoliarenko, M.V. Kaymakova, N.P. Belyatsky. Some aspects of personnel activity management of the enterprises were also be considered by scientists of V.R. Vesnin, O.S. Vikhansky, O.I. Naumov, B.M. Ginkin, R.A. Fathutdinov, G.A. Dmitrenko, O.M. Kryvoruchko, D.P. Goddess, O.V. Volkova, O.P. Yehorshin, E.M. Kailuk, A.M. Kolot, O.V. Fedosova, V.M. Lich, V.G. Fedorenko, V.O. Pokolenko, N.P. Ivleva.

The available works do not take into account the construction specifics, which must be taken into account when solving the tasks of assessment, motivation, preparation, retraining and advanced training of personnel in the construction industry.

The main features of construction that affect the process of personnel and production management, include the following:

- the uniqueness of the vast majority construction sites, which determines the need for the development of new project documentation, and therefore organizational and technical solutions;

- the variety of construction work types;

- long life construction products cycle (may be more than 100 years) in combination with the need to ensure the construction objects operation safety throughout the cycle;

- assessment of the management decisions economic effectiveness is complicated by the considerable duration of construction projects $(\mathrm{CP})$;

- the qualification of management personnel (at the stage of preparation and implementation) and production (in the process of construction works implementation) greatly affects the safety of the construction object further operation.

- Many stages of CP preparation, a large number of participants, combined with the complex process of workflow organization, which results in the complexity of determining the subject and the level of responsibility for ambiguous or wrong decisions.

The results of the conducted researches show that in the last decades there is a steady tendency to decreasing of construction works quality, widespread involvement of unskilled or low skilled workers in work performance, decrease of engineering and technical workers preparation quality.

Thus, the question of the existing methods, models, mechanisms of personnel management improving, taking into account the specifics of the features and current needs of the construction industry is relevant. 
The purpose of the work is to improve the scientific and methodological bases of construction enterprises personnel management.

The main material.

Management, as a process of impact on the object, is realized through the application of various, purposeful, interrelated, mutually supportive measures, which are selected taking into account the basic management methods such as economic, administrative (organizational-administrative), social and psychological, and are implemented through the use of developed relevant mechanisms.

Therefore, personnel management is being considered as a process of the enterprise personnel influencing through the implementation of a set of interrelated measures, in order to achieve it such state that most effectively ensures the achievement of the goals that are set before the organization.

A set of indicators is characterized the condition of the staff. At some point in time they are recognizes its quality and the level of its functional duties fulfillment. An appropriate system is created for the implementation of personnel management functions in the organization.

Based on the analysis of existing approaches, the construction of a personnel management system (MS) can be represented as a system of dependent characteristics functions: the goals of the organization (G), the used methods of personnel management $(\mathrm{Mt})$, the functions of personnel management $(\mathrm{F})$ and the mechanisms of personnel management $(\mathrm{Mx})$ :

$$
M S=\left\{\begin{array}{c}
f_{1}\left(\mathrm{G}_{1} \ldots . \mathrm{G}_{n}\right)=0 \\
f_{2}\left(\mathrm{M} t_{1} \ldots . \mathrm{M} t_{n}\right)=0 \\
f_{3}\left(F_{1} \ldots . \mathrm{F}_{n}\right)=0 \\
f_{4}\left(\mathrm{Mx}_{1} \ldots . \mathrm{Mx_{n }}\right)=0
\end{array}\right.
$$

The personnel management system of the construction company (Fig. 1) should take into account the peculiarities of the industry management:

- specialization of organizations in:

$o$ stages of work (design, survey, construction);

$o$ types of work (zero cycle, installation of the building frame, finishing, special, etc.);

$o$ functions in the investment and construction process (investor, customer, contractor)

- strict technical regulation of all construction stages of the construction object;

- availability of a standardization framework, which contains the norms of labor losses for the execution of construction works: resource elementary estimated standards for construction, repair-construction and other works;

- reduction in the volume of construction groundwork, which leads to significant breaks in the construction organizations workload;

- high level of injury and occupational morbidity.

Generalization of the main tendencies of construction industry development in Ukraine indicates that one of the the construction industry main problems is the low quality of construction work, due, in particular, to the shortage of highly skilled management, engineering and labor personnel. Subjects of construction activity need to develop effective methods of personnel assessment and appropriate incentive mechanisms, retention of highly qualified personnel within the enterprise.

The purpose and methods of the organization personnel assessment depend on the subjects needs that interested in such assessment in the construction:

- the construction organization itself;

- the customer of construction products;

- an investor who invests in order to profit from the construction organization entrepreneurial activity;

- an investor who invests at the stage of construction and, upon completion of construction, receives a profit from the construction object. 


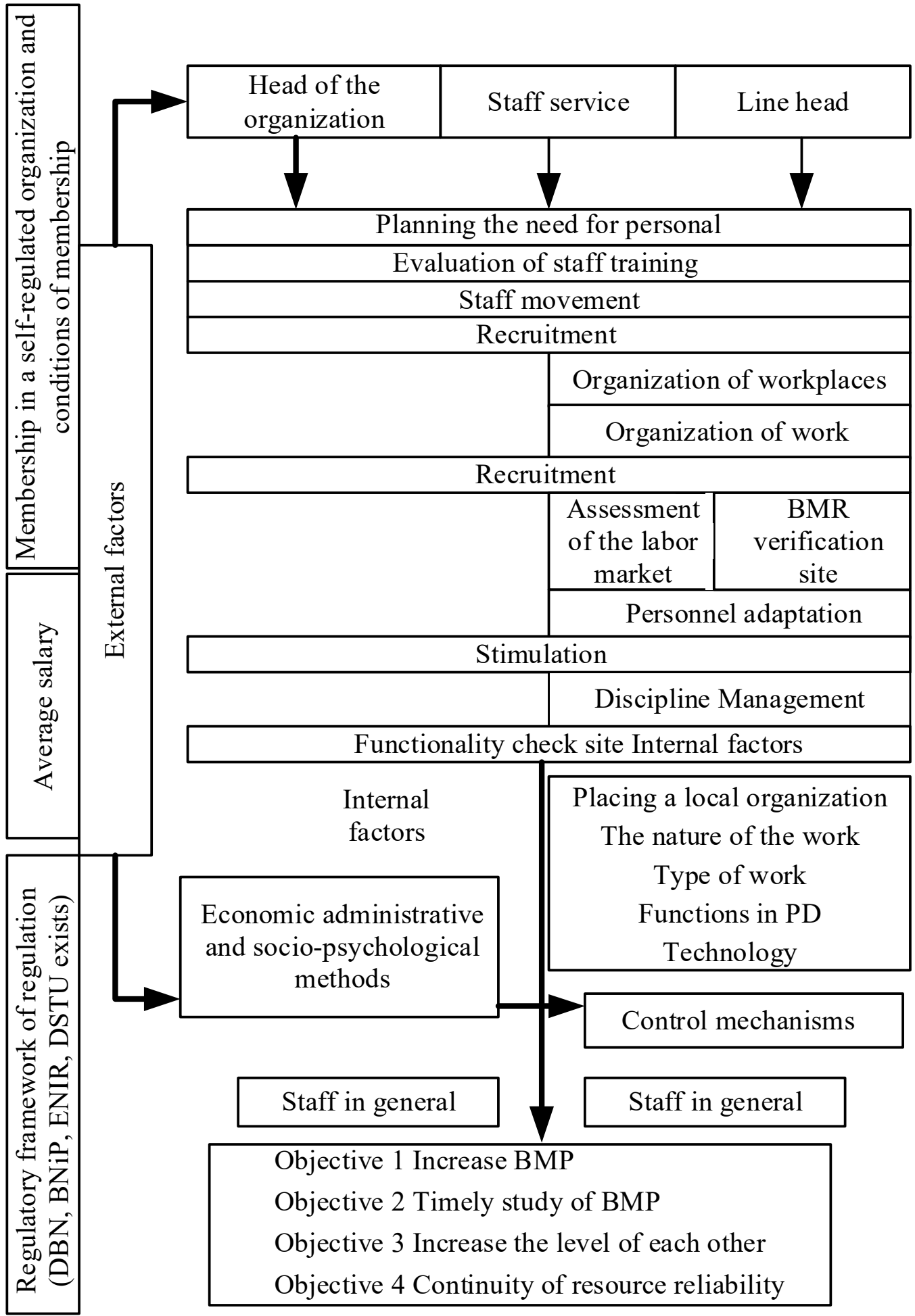

Figure 1 - Personnel management system of road construction management Рисунок 1 - Система управління персоналом дорожньо-будівельного управління 
The assessment of personnel is divided into internal, wich performed by the construction organization itself and external, performed by interested contractors.

In accordance with international quality management standards (150 9001), quality is the degree to which a set of intrinsic characteristics meets the requirements.

The above definition allows us to conclude that at first, quality must be quantified, since it is a degree of requirements satisfaction. Secondly, it is necessary to have a certain set of characteristics (parameters) of the object, which will evaluate its quality (in our case, the quality of personnel). Thirdly, the quality assessment depends on the list and the level of the subject requirements.

The list and level of requirements for the assessment subject depend on the assessment subject and its purpose. Depending on the purpose, different subjects will be prioritized for different entities in assessing the quality of construction organization personnel. Ensuring the right quality of products is a prerequisite for the enterprise competitiveness, which is also important for the investor.

The following characteristics can be used to evaluate the quality of construction organization personnel:

- skill level (Sl). This characteristic includes such elements as level of education, experience (seniority) of work, worker discharge, category of engineering and technical workers, a certificate from a responsible executor presence, a scientific degree or academic degree presence, possession of an employee of related professions, etc .;

- readiness and commitment to training, advanced training $(\mathrm{T})$

- employee's age (A);

- health status $(\mathrm{H})$;

- innovation (I) (adequate perception of innovation);

- labor productivity (LP) - output;

- array of individual psychological and physiological characteristics $(\mathrm{Ph})$, the set of which may vary depending on the specific requirements of the profession or position occupied by the employee (communication skills, perseverance, ability to work "in the press", attentiveness, meticulousness, presence of leadership qualities, commercial talent career growth).

Thus, a generalized staff quality index $(\mathrm{Qp})$ can be represented as a function:

$$
\mathrm{Qp}=\mathrm{F}(\mathrm{Sl}, \mathrm{T}, \mathrm{A}, \mathrm{H}, \mathrm{I}, \mathrm{LP}, \mathrm{Ph}) .
$$

Obviously, it is necessary to distinguish between the quality of the construction organization personnel as a whole and the quality of a particular category of workers, as well as the quality of an individual worker.

To determining the level of personnel quality, it is necessary to give value to each of the given characteristics and to compare with a certain standard. It can be predicted that the sum of the separate scores for each characteristic will give an overall estimate of the quality of the staff. The developed appropriate scale summary scores can be transformed into understandable verbal. The quality of the staff can be categorized as unsatisfactory, satisfactory and excellent.

Based on the results of the staff quality assessment, decisions regarding the need for employee training, upgrading, transfer to another position should be made and measures to motivate staff and the appropriateness of their work in the organization should be developed. 
For the customer and the investor the assessment of the personnel qualification level of the construction organization with the important from the point of view of its ability to provide high-quality and timely execution of construction works. For this purpose, as a rule, as part of the competitive bidding proposal, the contractor must provide the customer with information on ensuring the organization with management, engineering and technical staff, work experience, the conformity coefficient of the workers average grade to the average category of object works. Information indicating the qualification of the staff may also include the feedback of previous customers on the quality of the work performed.

The empowerment of the customer (investor) in carrying out the assessment of the contracting organization personnel qualification level can be ensured through the system of industry employees personal certification. In Ukraine, the current legislation provides for certification of responsible contractors for certain types of work (services) related to the creation of an architectural object (architects, design engineers, technical engineers and experts). Unfortunately, other employees of the industry, including chief engineers and superintendents, are not subject to the system of personal certification, which reduces the level of personal responsibility in the construction works execution/

A personal certification system can be both mandatory and voluntary and it is an effective means of furthering and assessing, as worldwide experience has shown,

It is determined that depending on the ame of the quality assessment of the staff a set of specific characteristics that make up the concept of "quality" depends on. Thus, guided by the purpose of the evaluation, it is possible to reduce the list of characteristics to be evaluated.

The main factors influencing the quality of constract works are: quality and timeliness of building materials, products, structures supply; providing workers with quality tools and controls; appropriate qualification of workers, foreman and master; their interest in quality work; careful implementation of intermediate and final controls; quality of production planned tasks. The relationship between the functions of the structural units of the building company and the factors they provide are presents in Figure 2

For each structural unit function the key characteristics that the personnel of this unit should have for the best implementation, which directly affect the quality of the constract works are highlighted (Table 1).

Features are divided into two groups - common to all units and specific, which are divided into objective and subjective. Objectives are evaluated on the basis of concrete work results, on indicators. Subjective characteristics are assessed by unit managers based on personal experience of communicating with specific employees, not documented statistics on their behavior.

Each subjective and objective criterion is assigned a weighting factor and a rating scale is proposed. Weighting factors for determining common characteristics for workers and engineering staff are different.

In order to simplify the expert evaluation, it is suggested to use the apparatus of fuzzy mathematical logic. One of the basic tenets of the theory of fuzzy sets is to remove the clear distinction between belonging (value 1) and non-belonging (value 0 ) of elements to a set. The attribution of element $\mathrm{X}$ to set $\mathrm{A}$ is described by values that lie in the interval between 0 and 1 , and linguistic variables can be used to describe these values. For example, a subjective characterization of staff, such as an interest in quality work, can be described not only as "high interest" or "lack of interest", but also "low interest", "average interest". The value of a linguistic variable is coordinated with a corresponding scale in points: for example, "lack of interest" - 0 points, "low interest" - 3 points, "average interest" - 5 points, "high interest" - 10 points. 


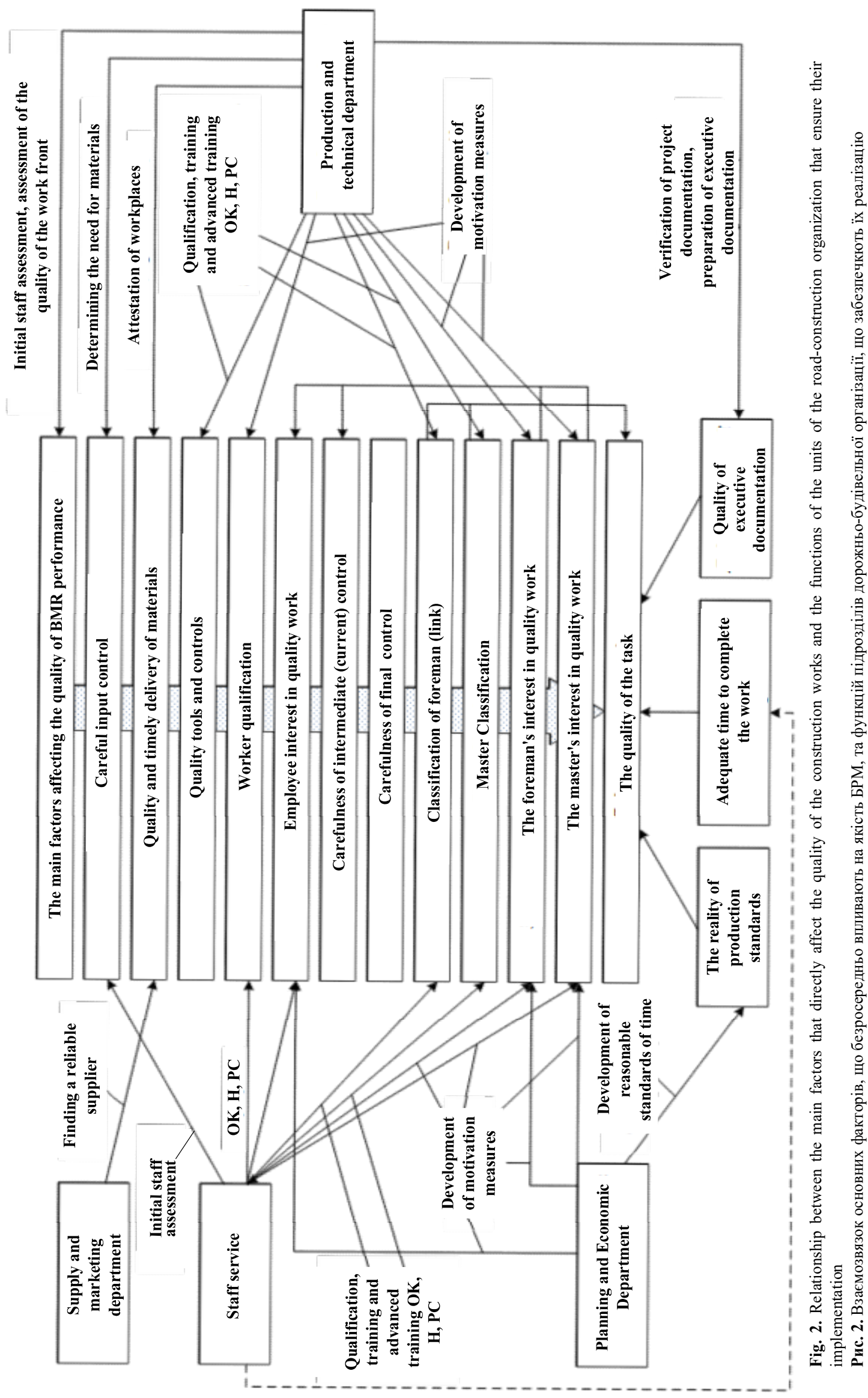


Estimates in fuzzy logic theory are interpreted as an accessories function. An expert or decision maker determines the value of accessories function.

Suppose that $A=\{a 1, a 2, \ldots$, an $\}=\{a 1, j=(1, n)\}$ is the set of employees to be evaluated;

$\mathrm{K}=\{\mathrm{k} 1, \mathrm{k} 2, \ldots, \mathrm{kn}\}$ is the set of subjective criteria that characterize these workers, where - $\mathrm{k} 1$ is interest in high quality work; $\mathrm{k} 2$ - honesty (level of trust in the employee); $\mathrm{k} 3$ - stress resistance; $\mathrm{k} 4$ - the desire for development.

According to the results of the assessment, it is considered appropriate to introduce adequate measures to encourage employees to achieve this goal.

In order to ensure the quality of the constract work performance, we will offer a mechanism of incentives for construction organization employees, taking into account their results (Fig. 3). This mechanism is based on a systematic assessment of personnel quality by the criterion "Quality of construction work performance and monthly assessment of functional responsibilities performance by each individual employee and the unit as a whole".

Based on the results of the staff quality assessment, which is proposed to be conducted once every half year, tariff rates, salaries, unit rates are set and adjusted, and thus the level of basic salary is determined for the next half year. Based on the results of the individual assessment, for the technical workers, coefficients of labor participation (KLP) are established, on the basis of which the supplementary payroll of the unit is distributed. The total additional salary fund for the units and the workers individual labor participation rate is determined by the results of the functional duties fulfillment level assessing (on a monthly quantitative indicators basis). Such mechanism ensures transparency in the principles of the distribution of material remuneration and incentives for employees, which should increase their level of diligence and responsibility.

According to the year results, the final assessment of each employee in points (which are accumulated annually) is determined. We propose to establish an incentive system based on cumulative rating accumulated over 1, 3, 5, 7 and 10 years. The cumulative principle of the proposed mechanism will facilitate the growth of the most experienced, responsible and skilled workers in organizing the employment potential.

A quantitative correlation between the constituent qualities of the construction organization's staff and income is established according to the research.

Based on statistics on the construction organizations activities, we have developed a regression model of the net income dependence on the production, structure of personnel by age, qualification, intensity of training and improvement of staff qualification in the past years.

It is proposed to use the indicator "cost of personnel", As a criterion for assessing the quality of personnel from the investor's point of view. It is defined as the net income / sales, reduced by the amount of material costs and depreciation of fixed assets of the enterprise, the indicator - characterizing the value contribution of staff at all levels in the organization's income.

Measures have been developed to improve the "qualification component of staff quality" in construction industry in Ukraine, in particular, involving the joint efforts of self-regulatory organizations (CO) members (Fig. 4). 
Table 1 - Assessment of the quality of construction organization personnel to ensure the construction work implementation

Таблиця 1 - Оцінка якості персоналу дорожньо-будівельної організації для забезпечення виконання БМР

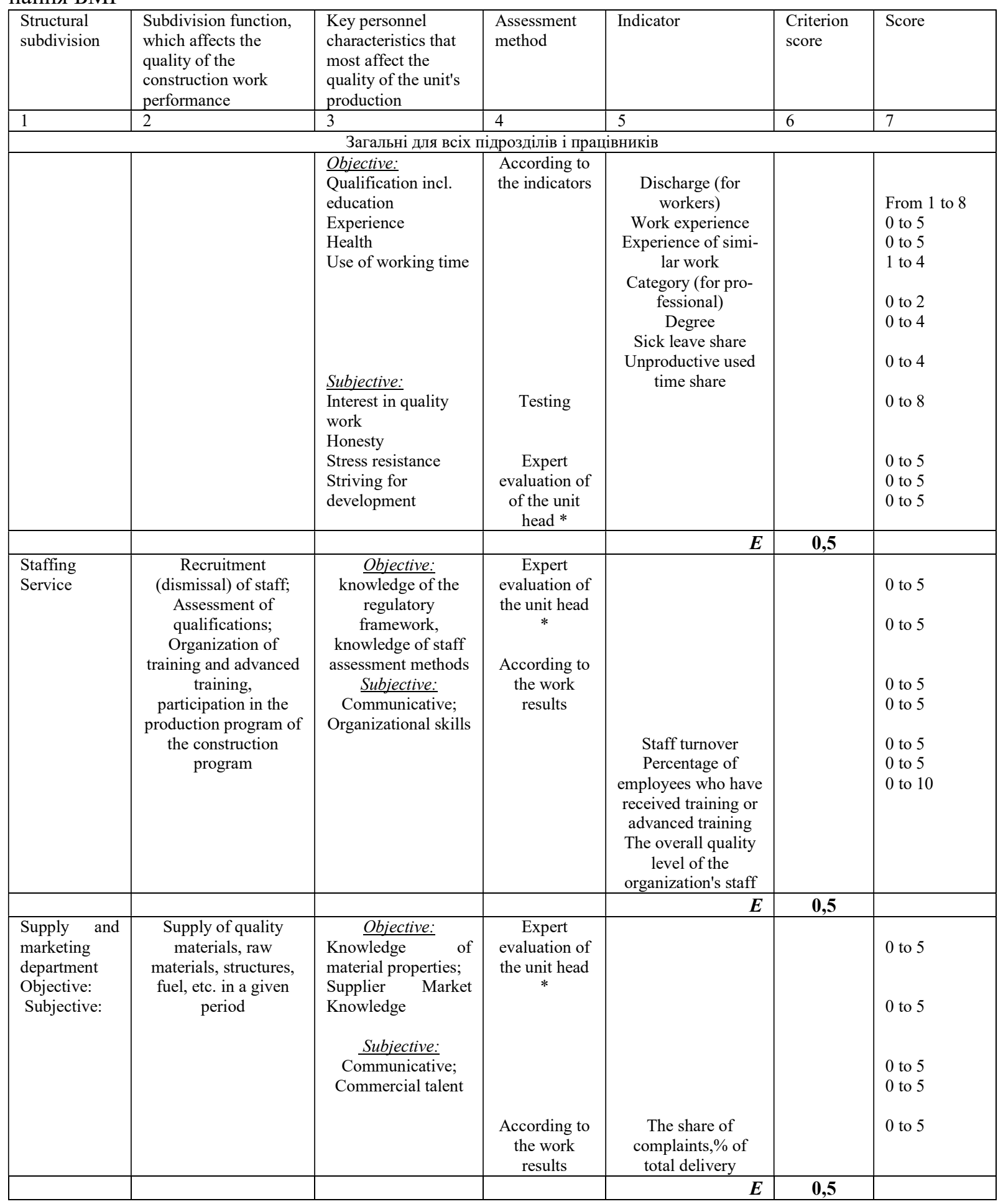


Continued table 1

\begin{tabular}{|c|c|c|c|c|c|c|}
\hline \multicolumn{7}{|c|}{ Characterized by individual units } \\
\hline \multirow[t]{2}{*}{$\begin{array}{c}\text { Planning and } \\
\text { economics } \\
\text { department }\end{array}$} & $\begin{array}{c}\text { Production of } \\
\text { development program; } \\
\text { Rationing of labor; } \\
\text { Rationale for wages, } \\
\text { bonuses }\end{array}$ & $\begin{array}{l}\text { Objective: } \\
\text { Knowledge of the } \\
\text { normative base of } \\
\text { the labor economy } \\
\frac{\text { Subjective: }}{\text { Creative approach to }} \\
\text { work }\end{array}$ & $\begin{array}{c}\text { Expert } \\
\text { evaluation of } \\
\text { the unit head } \\
*\end{array}$ & $\begin{array}{l}\text { The general level } \\
\text { (by the enterprise) } \\
\text { of the staff's interest } \\
\text { in the quality of the } \\
\text { work performed }\end{array}$ & & 0 to 5 \\
\hline & & & & $\boldsymbol{E}$ & 0,5 & \\
\hline \multirow[t]{2}{*}{$\begin{array}{c}\text { Production } \\
\text { and Technical } \\
\text { Department }\end{array}$} & $\begin{array}{l}\text { Proposals to determine } \\
\text { the need for workers, } \\
\text { their characteristics; } \\
\text { Participation in the } \\
\text { assessment of workers' } \\
\text { skills; Organization of } \\
\text { training and advanced } \\
\text { training in production; } \\
\text { Participation in the } \\
\text { development of } \\
\text { approaches to } \\
\text { employee motivation }\end{array}$ & $\begin{array}{c}\text { Subjective: } \\
\text { Leadership abilities; } \\
\text { Organizational } \\
\text { abilities; } \\
\text { Ability to work in a } \\
\text { team; } \\
\text { Ability to work } \\
\text { "under the press" }\end{array}$ & $\begin{array}{c}\text { Expert } \\
\text { evaluation of } \\
\text { the unit head } \\
* \\
\text { According to } \\
\text { the work } \\
\text { results }\end{array}$ & $\begin{array}{l}\text { Share of cost of } \\
\text { works to eliminate } \\
\text { deficiencies from } \\
\text { the total amount of } \\
\text { work, } \%\end{array}$ & & $\begin{array}{l}0 \text { to } 5 \\
0 \text { to } 5 \\
0 \text { to } 5 \\
0 \text { to } 5 \\
0 \text { to } 5\end{array}$ \\
\hline & & & & $E$ & $\mathbf{0 , 5}$ & \\
\hline \multirow[t]{2}{*}{$\begin{array}{l}\text { Brigade } \\
\text { Brigadier, } \\
\text { workers }\end{array}$} & $\begin{array}{l}\text { Construction work } \\
\text { implementation } \\
\text { Subjective: } \\
\text { Absence of bad habits } \\
\text { Team Leadership } \\
\text { Expertise * } \\
\text { According to the } \\
\text { results of work }\end{array}$ & $\begin{array}{l}\text { Subjective: } \\
\text { Absence of bad } \\
\text { habits } \\
\text { Ability to work as a } \\
\text { team }\end{array}$ & $\begin{array}{c}\text { Expert } \\
\text { evaluation of } \\
\text { the unit head } \\
\qquad * \\
\text { According to } \\
\text { the work } \\
\text { results }\end{array}$ & $\begin{array}{l}\text { Share of workload } \\
\text { of inadequate } \\
\quad \text { quality } \\
\text { Degree of non- } \\
\text { compliance with the } \\
\text { work quality } \\
\text { requirements }\end{array}$ & & $\begin{array}{l}0 \text { to } 5 \\
0 \text { to } 5 \\
0 \text { to } 5\end{array}$ \\
\hline & & & & $E$ & 0,5 & \\
\hline
\end{tabular}

\section{Conclusions}

1. The global trends in the development of construction are; increasing requirements for the quality of construction work, reducing the professional qualification of a large proportion of construction workers, the lack of highly qualified engineering and technical staff, the widespread temporary staffing system for the implementation of the project, increasing the share of construction projects in the projects that are being implemented difficult conditions, which leads to a decrease in labor productivity of workers, requires high skills, increases the level of responsibility for the wrong organizational and technical decisions. The peculiarities of personnel management in the construction industry and the above development trends necessitate the improvement of existing personnel management mechanisms in construction.

2. Effective resolution of these problems requires that the personnel management system of the construction organization is built on an increase of the personnel service role. The head of staff in the construction organization structure must have the same level of authority as the deputy director of finance and production. 


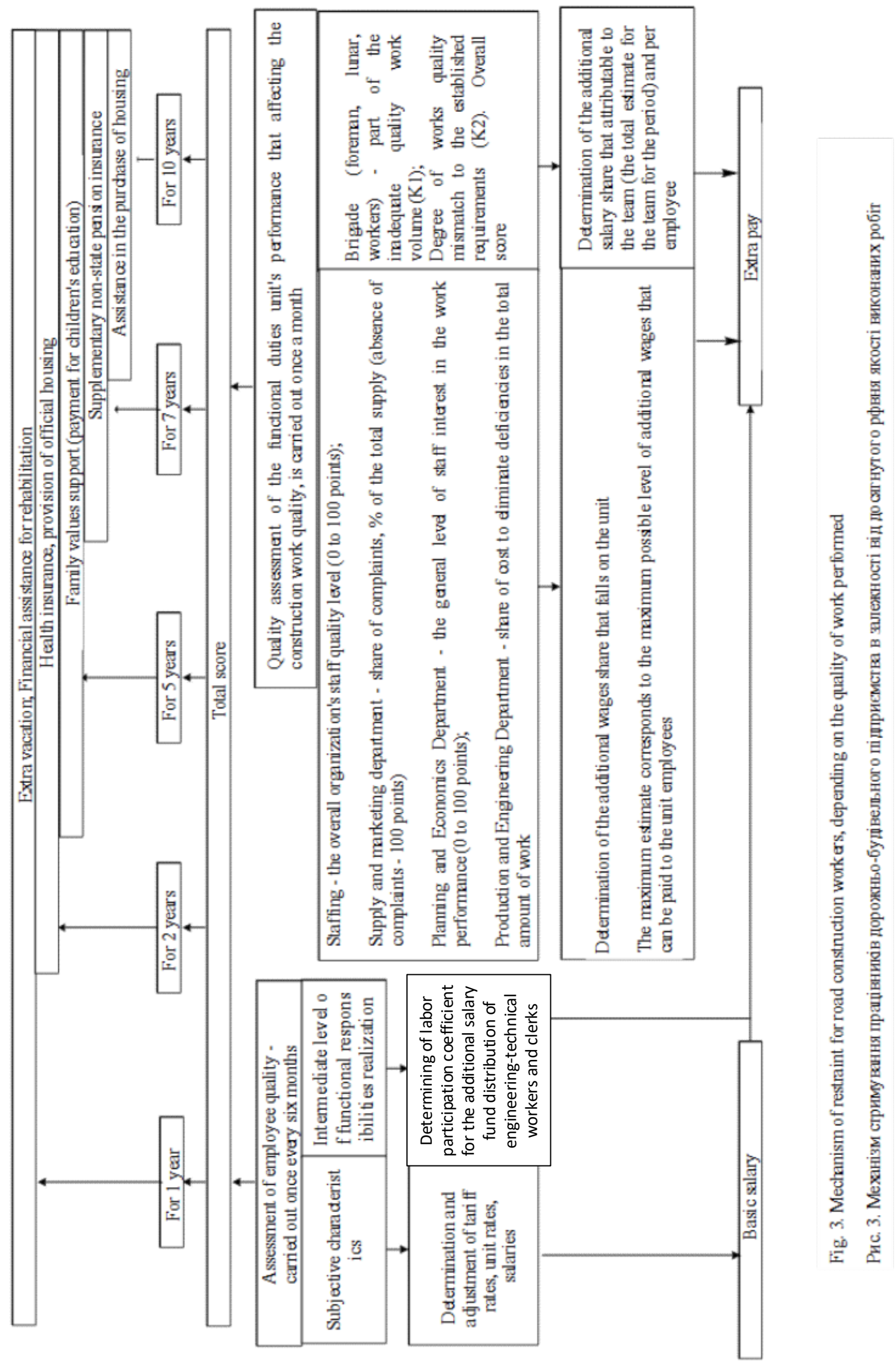




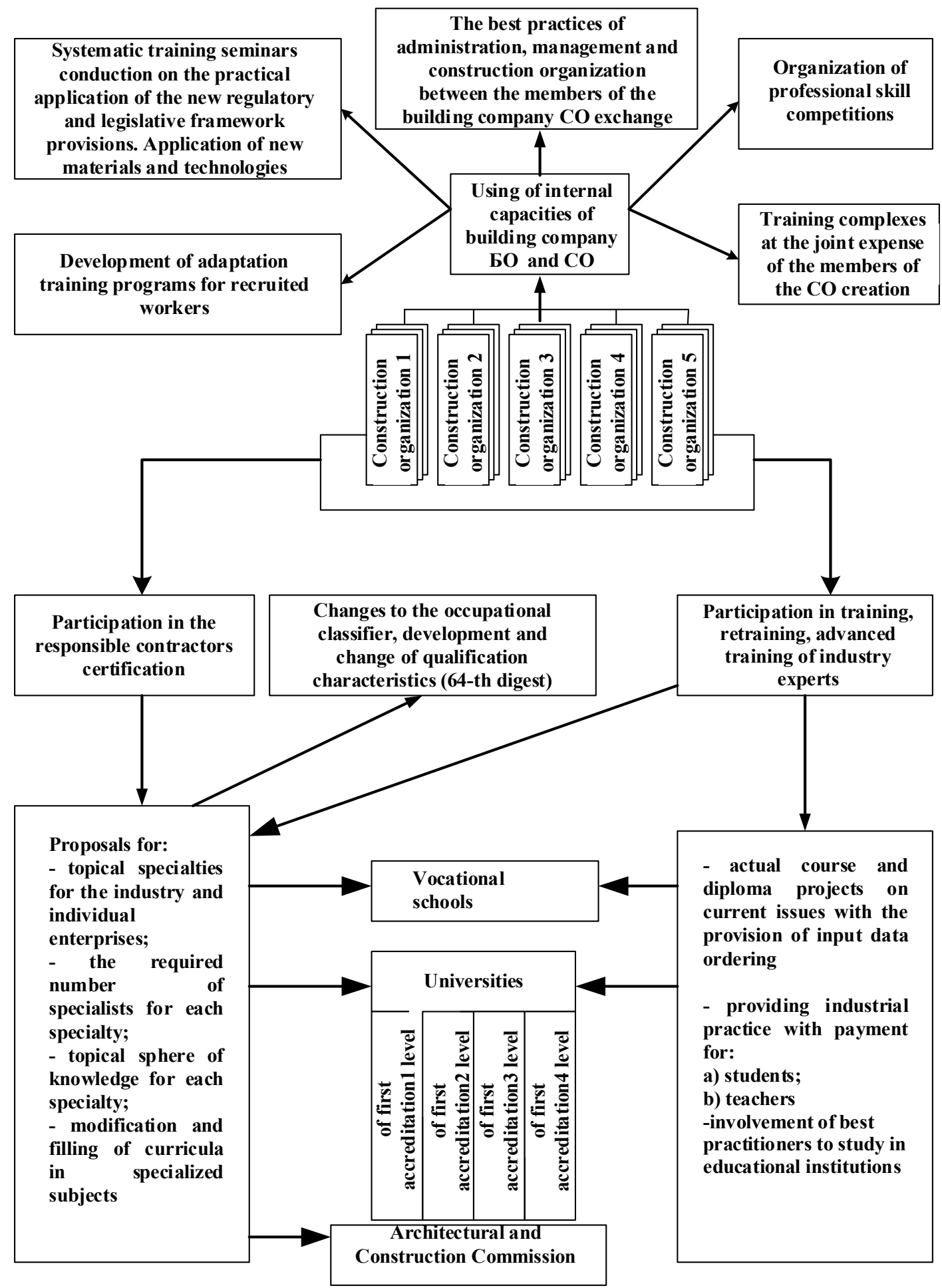

Figure 4 - Measures have been developed to improve the "qualification component of staff quality" in the road construction industry of Ukraine with the involvement of self-regulatory organizations (SO) members joint efforts

Рисунок 4 - Розроблені заходи щодо підвищення «кваліфікаційної складової якості персоналу» в дорожньо-будівельній галузі України з залученням спільних зусиль членів саморегулюючих організацій (СО) 
3. The modern interpretation of the personnel management concept in construction is defined. It is the process of applying a set of interconnected activities to help staff achieve the necessary state to maximize the effectiveness of the construction organization's goals.

4. It is clear that the staff condition is determined by a set of indicators that would be able to determine the staff quality and the level of their functional responsibility fulfillment. A new set of characteristics is proposed to assess the quality of construction organization personnel. It includes: qualification level, ability and willingness to study or advanced training, employee's age, health status, tendency to innovate, productivity, individual psychological and physiological characteristics, the recruitment of which may vary depending on the specific requirements of the profession or position, which occupied by an employee.

5. The authors found that a prerequisite for the staff quality level assessment is to determine the purpose of the organization for the implementation of which staff is evaluated. The set of staff characteristics and their rank in the overall staff assessment should depend on the purpose of the organization. With this ame, a system of construction company personnel quality assessment for the needs of the enterprise itself is proposed. It is based on a factor-based approach and provides for the identification of structural units that ensure the achievement of the goal (quality, timely execution of construction works, profitability of activity, uniform load of resources) tasks, definition of staff influential characteristics. The implementation of the proposed approach to assessing the construction organization staff quality contributes to the effectiveness of the organization, and, in particular, to improve organizational relationships.

6. The proposed mechanism of employee incentives, taking into account the personal results achieved, contributes to increasing the level of interest in achieving the organization goal, and maintain its highly skilled labor potential.

7. According to the results of the calculations, a quantitative link between the constituents of the "quality of construction organization staff" and the net income of the construction organization was established. It can be used to analyze the internal reserves of the organization with the place of increasing its efficiency.

8. It is proposed to assess the personnel quality from the investor's point of view by the criterion of "personnel cost". It is defined as the net income from the construction and assembly works realization, reduced by the amount of material costs and depreciation of the organization fixed assets. This indicator characterizes the value of staff contribution at all levels in the organization's income.

9. Developed measures of the "qualification component of the personnel quality" of the construction industry improving, are based on the joint efforts of the investment construction process subjects. They help to improve the construction products quality while reducing the costs of building organizations to improve the employees skills.

\section{References}

1. Taryfna systema oplaty pratsi ta yiyi efektyvnist'. Ekonomika: problemy teoriyi ta praktyk): : zb. nauk. pr. Dnipropetrovs'k : DNU, 2007. - Vyp. 225, t. 11 -S. 535-541.

2. 18 Pytannya normuvannya pratsi v budivnytstvi // Shlyakhy pidvyshchennya efektyvnosti budivnytstva $v$ umovakh formuvannya rynkovykh vidnosyn» : zb. nauk. pp. K : KNUBA. 2011. Vyp. 24. S. 164-169.

3. Slipenchuk H.V. Sutnist' zarobitnoyi platti yak ekonomichnoyi katehoriyi v systemi rynkovykh rozpodil'nykh // Materialy VII Mizhnar. nauk.-prakt. konf., 26 lystom. 2008 r. - K : IVTS Vydavnytstvo «Politekhnika», 2016-259s.

4. Slipenchuk H.V. Rozvytok systemy otsinky rivnya kvalifikatsiyi personalu budivel'nykh orhanizatsiy v Ukrayini // Materialy II Vseukr nauk.- prakt. konf. stud. ta molodykh vchenykh «Suchasni problemy mizhnarodnoyi ekonomiky». Dnipropetrovs'k. 2017. - S. 108-110.

5. Slipenchuk H.V. Pytannya sertyfikatsiyi personalu v budivnytstvi . Tezy dopovidey Nauk. konf. molodykh vchenykh, asp. i stud.: v 2-kh ch K.: KNUBA. 2016h CH. 2. - S. 62-63. 


\section{УПРАВЛІННЯ ПЕРСОНАЛОМ ДОРОЖНЬО-БУДІВЕЛЬНИХ ПІДРИЕМСТВ}

Гречан Алла Павлівна, доктор економічних наук, професор, Національний транспортний університет, професор кафедри економіки, e-mail: grechan.ap@gmail.com, тел. +380674494014, Україна, 01010 , м. Київ, вул. М.Омельяновича-Павленка, 1., https://orcid.org/0000-0002-4067-4371

Яценко Богдан Ігорович, кандидат економічних наук, Державний університет інфраструктури транспорту, super_inna@ukr.net, tel. 0939989850, Україна, 04071, Київ, вул. Кирилівська, 9. https://orcid.org/0000-0001-7080-7254

Петрович Володимир Васильович, кандидат технічних наук, професор, старший науковий співробітник, професор кафедри транспортного будівництва та управління майном Національного транспортного університету. e-mail: petrovichvv60@ukr.net, тел. +3804428027338, Україна, 01010, м. Київ, вул. М. Омеляновича-Павленка, 1, к. 138., https://orcid.org/0000-0003-0422-2535

Усиченко Олена Юріївна, кандидат технічних наук, доцент, професор кафедри транспортного будівництва та управління майном Національного транспортного університету, fbbk@ukr.net, тел. $+380442807338,+380442803942$, Україна, 01010, м. Київ, вул. М. Омеляновича-Павленка, 1, к. 138. https://orcid.org/0000-0002-7482-8420

В роботі розглянуто особливості управління персоналом в будівельній галузі. Запропоновані концептуальні засади побудови системи управління персоналом будівельної організації, в основі якої покладено підвищення ролі служби персоналу. Вдосконалений механізм оцінки якості персоналу будівельною підприємства з позиції самого підприємства, заснований на факторно-цільовому підході, що полягає у виділенні визначальних задач структурних підрозділів, які необхідно вирішити для досягнення поставленої мети, визначення га оцінки відповідних ключових характеристик персоналу.

Встановлено кількісний зв'язок між складовими якості персоналу будівельної організації та чистим доходом будівельної організації.

Оцінку якості персоналу з позиції інвестора здійснювати за критерієм «вартість персоналу, який визначається як чистий дохід реалізації будівельно-монтажних робіт, зменшений ми величину матеріальних витрат та амортизації основних фондів організації.

Розроблений механізм стимулювання працівників будівельної організації в залежності від досягнутого рівня якості виконаних робіт. Запропонований комплекс заходів, що спрямовані на підвищення «кваліфікаційної складової» якості персоналу будівельної) галузі.

Ключові слова: управління персоналом, будівництво, якість персоналу, стимулювання, підвищення кваліфікації.

\section{Перелік посилань}

1. Тарифна система оплати праці та її ефективність. Економіка: проблеми теорії та практик): : зб. наук. пр. Дніпропетровськ : ДНУ, 2007. - Вип. 225, т. 11 -С. 535-541.

2. 18 Питання нормування праці в будівництві // Шляхи підвищення ефективності будівництва в умовах формування ринкових відносин» : зб. наук. пр. К : КНУБА. 2011. Вип. 24. - С. $164-$ 169.

3. Сліпенчук Г.В. Сутність заробітної платті як економічної категорії в системі ринкових розподільних // Матеріали VII Міжнар. наук.-практ. конф., 26 листом. 2008 р. - К : ІВЦ Видавництво «Політехніка», 2016- 259c.

4. Сліпенчук Г.В. Розвиток системи оцінки рівня кваліфікації персоналу будівельних організацій в Україні // Матеріали II Всеукр наук.- практ. конф. студ. та молодих вчених «Сучасні проблеми міжнародної економіки». Дніпропетровськ. 2017. - С. 108-110.

5. Сліпенчук Г.В. Питання сертифікації персоналу в будівництві . Тези доповідей Наук. конф. молодих вчених, асп. і студ.: в 2-х ч К.: КНУБА. 2016 г Ч. 2. - С. 62-63. 